\title{
Effect of Foliar Application with Aloe Leaf Extract (ALE) on Vegetative Growth, Oil percentage and Anatomical leaf Structure of Sage (Salvia officinalis L.) Plant under Sand soil Conditions
}

\author{
Soha M. T. M. Abbas ${ }^{1 *}$; M. A. Zaglool ${ }^{2}$; E. A. E. El-Ghadban ${ }^{1}$; S. E. H. Abd El-Kareem ${ }^{2}$ and A. A. Waly ${ }^{2}$ \\ ${ }^{1}$ Medicinal and Aromatic Plants Research Department, Horticulture Research Institute, Agric. Res. Center, Giza, Egypt. \\ ${ }^{2}$ Horticulture Department, Faculty of Agriculture, Suez Canal University, 41522, Ismailia, Egypt.
}

Received: $15 / 8 / 2016$

\begin{abstract}
The present study was carried out at the Experimental Farm, Horticulture Department, Faculty of Agriculture, Suez Canal University in two successive seasons (2012 \& 2013). The aim of this work was to study the effect of aloe leaf extract (ALE) at $0.0,10,20$ and $40 \mathrm{ml} / \mathrm{L}$ on vegetative growth, yield, essential oil percentage and leaf anatomical structure of sage plants ( Salvia officinalis L.) under sandy soil condition. Aloe leaf extract (ALE) especially at highest concentration $(40 \mathrm{ml} / \mathrm{L})$ significantly increased the plant height, number of leaves, number of branches, yield and essential oil percentage as well as enhancement the leaf anatomical structure. The obtained results led to recommended producing higher yield and essential oil percentage grown in sandy soil using Aloe leaf extract.
\end{abstract}

Keywords: Aloe vera, ALE, plant extract, sage, Salvia officinalis L., yield and essential oil, leaf anatomical structure.

\section{INTRODUCTION}

Sage (Salvia officinalis L.) belongs to the family Lamiaceae; it is a perennial medicinal and aromatic which is rich in volatile oils. It has been used for different diseases including respiratory infection, menstrual difficulties and digestive complaints. The fresh leaves are used for whiten the teeth, while the dried ones are used cosmetically to restore.

In Egypt, the total cultivated area of sage plants is about 220 fed. and produced about 1.59 ton/fed of herb (Ministry of Agric., 2016).

However, we must expansion in medicinal and aromatic plants production because of our suitable climatic conditions, abundance of employment, abundance of reclaimed sandy soil.

Chemical fertilizers are important source of plant nutrition, but they are expensive and represent a source of environmental pollution. Also, chemical fertilizers at high rates for long time may increase the dangerous effect of chemical residual in plant tissues on the human health and animal consumers.

Thus, it has led growers of medicinal and aromatic plants to use many plant extracts to improve and stimulate both the plant growth and the active ingredients instead of use chemical compounds. One of these extracts that used in this experiment is Aloe vera Extracts (AVE) which extracted from the leaves of Aloe plants.

Aloe vera belonging to family Alliaceae is succulent herb. It contains all the essential amino acids, i.e. isoleucine, leucine, lysine, methionine, phenylalanine, threonine, valine and tryptophan. It also contains few other non-essential amino acids, which are alanine, arginine, asparagin, cystenien, glutamic acid, glycine, histidine, proline, serine, tyrosine, glutamine and aspartic acid. More over it contains mono polysaccharide (cellulose, glucose, mannose, aldopentose), lignin, macro nutrients $(\mathrm{N}, \mathrm{P}, \mathrm{K})$, secondary nutrients $(\mathrm{Mg}, \mathrm{Ca})$, micro nutrients/trace elements ( $\mathrm{Zn}, \mathrm{Fe}, \mathrm{Mn}, \mathrm{Cu})$, vitamins (B1, B2, B6, C, niacin, collin, enzyme, innositol, aloin, iso barbaloin, aloe emodin, natural hormones $0.63 \mathrm{mg} / 100 \mathrm{~g}$ F.W., gibberellins $16.00 \mathrm{mg} / 100 \mathrm{~g}$ F.w. and salicylic acid (Shyamal et al., 1990; Rajeswari et al, 2012; Hamouda et al., 2012; Sahu et al., 2013 and Raman et al., 2013).

Aloe leaf extract (ALE) used to improve the vegetative growth (Youssef, 1997) and could be useful as natural plant growth regulator on sweet basil (Dongzhi et al., 2004). Nour El- Din (2005) on Majorana hortensis, M., Mady (2008) on Majorana hortensis and Salvia officinalis L. and Hamouda et al. (2012) on sweet basil, they reported that foliar spraying with Aloe vera extract improved growth and yield. In addition, the previous information about the effect of spraying aloe extract on anatomical structure of vegetative organs of sage plant or other related species are not available in the literature.

Therefore, the present work aimed to study the effect of different spray rates with aloe leaf extract (ALE) on vegetative growth, yield and essential oil percentage as well as leaf anatomical structure of sage plants under sandy conditions.

\section{MATERIALS AND METHODS}

This work was carried out at the Experimental Nursery of the Department of Ornamental Horticulture, Faculty of Agriculture Suez Canal University, Ismailia, Egypt during the two successive seasons of (2012 \& 2013). Sandy soil with $\mathrm{pH}$ values of 7.22 and 7.52 and contained $28.00 \& 22.00 \mathrm{mg} \mathrm{kg}^{-1}$ available $\mathrm{N}, 14.51$ \&20.50 mg kg- ${ }^{1}$ available $\mathrm{P}, 105 \& 139 \mathrm{mg} \mathrm{kg-}^{1}$ available $\mathrm{K}$ and $0.357 \& 0.288 \mathrm{mg} \mathrm{kg-}^{-1}$ organic matter was used in the two seasons, respectively.

In early January of both seasons, the soil was divided into plots $(2.5 \times 2.5 \mathrm{~m})$ and amounted of cattle manure with $25 \mathrm{~m}^{2} /$ fed was added for each plot by mixing mixed with the soil during the preparation process, five weeks before planting. The physical and chemical characteristics of cattle manure are presented in Table (1).

The plot is containing 3 rows of $60 \mathrm{~cm}$ apart and $2 \mathrm{~m}$ length. Sage plants of were planted in $20^{\text {th }}$ and $7^{\text {th }}$ 
February for the first and second seasons, respectively. The spacing between plants was $30 \mathrm{~cm}$, since the number of plants was 3 in each row and 9 plants per plot.

Leaves of Aloe vera were cold pressing by using a stainless steel drums to obtain the extracted solution gel of aloe leaves, the obtained extract was filtrated according to Shyamal et al. (1990).

The extract (ALE) was used at 10, $20 \& 40 \mathrm{ml} / \mathrm{L}$ water and used for foliar spraying of sage plants at three equal doses for every cut during the two growing seasons. The first addition was done one month after cultivations, while the other applications were applied 15 day intervals after the first application, respectively. The control treated sprayed with water.

Table (1): Physical and chemical characteristics of the cattle manure used for fertilization of sage plants during 2012 and 2013 seasons.

\section{Properties}

First season Second season

\begin{tabular}{lll}
\hline EC dSm-1 & 0.85 & 1.09 \\
pH & 7.11 & 7.66
\end{tabular}

Cations meq $/ \mathbf{L}$

$\begin{array}{lcc}\mathbf{C a}^{2}+ & 4.00 & 5.00 \\ \mathbf{M g}^{2}+ & 8.00 & 6.00 \\ \mathbf{N a}+ & 17.00 & 12.0 \\ \mathbf{K}+ & 22 & 15\end{array}$

Anions meq/L

Cl-

HCO-3

6.00

$\mathrm{SO}_{4}$

25.0

7.00

$\mathrm{CO}_{3}{ }^{2-}$

0.0

14.0

Total N mgkg- ${ }^{1}$

1.63

0.0

1.07

Available N mgkg-1

254

294

Available P mgkg-1

160

127

Available K mgkg-1

1040

1200

$\mathrm{C} / \mathrm{N}$ ratio

12.58

16.14

Organic Carbon gkg-1

205

279

Organic Matter gkg-1

353

48.2

Moisture\%

4.00

7.90

Fe mgkg- ${ }^{1}$

2388

2966

Cu mgkg-1

16.61

11.67

Mn mgkg-1

190.3

189.8

Zn mgkg-1

30.34

39.45

The experimental design was a randomized complete blocks, where the experiment involved 4 treatments with three replicates (plots).
The plants were irrigated whenever they needed and all of the cultural practices were followed as normal.

The harvesting process was taken place on $29^{\text {th }}$ May 2012, $15^{\text {th }}$ May 2013 for the first cut, and in $3^{\text {rd }}$ September 2012, $15^{\text {th }}$ August 2013 for the second cut, respectively.

At the harvesting time, data were recorded concerting the vegetative growth presented in plant height $\mathrm{cm}$, number of leaves /plant, leaf area, and number of main branches/plant, fresh and dry weights of herb/plant gm.

The essential oil percentage of each treatment of sage plants was determined in the fresh herb using water distillation method according to the British Pharmacopoeia (1963).

For anatomical study, leaf samples for the most effective treatment to essential oil production of sage plants $(40 \mathrm{ml} \mathrm{ALE} / \mathrm{L})$ and control treatment were taken in the second season at the time of the second cutting, killing and fixation in 70\% FAA solution, dehydration, clearing with n- butyl alcohol series and embedded in paraffin wax of $56-58^{\circ} \mathrm{c}$. Using a rotary microtome, sections $(20 \mu)$ were cut and stained with safranin and light green before mounting in Canada balsam. Slides were examined microscopically and photomicrography (Nassar and El-Sahhar, 1998).

Data were statistically analyzed with the analysis of variance using a computer statistical software SPSS program Version 12.0, (copy right $(2003$ for SPSS Inc., USA). Results were displayed as the differences between the means treatments and tested using modified L.S.D. The means were significantly different if the $\mathrm{P}$ value was $=0.5$ according to Snedecor and Cochran (1980).

\section{RESULTS AND DISCUSSION}

Effect of (ALE) on vegetative growth: Plant height (cm):

Data in Tables (2 \& 3) show that increasing the rates of ALE significantly increased the plant height of sage. This result was confirmed in two cuts and in the two seasons.

In this concern, the highest concentration of ALE $(40 \mathrm{ml} / \mathrm{L})$ significantly produced the longest plant height as $64.38-70.75$ and $66.79-67.24 \mathrm{~cm}$ for the first and second seasons and its two cuts, respectively. On the other side, the shortest plants 42.93 and 38.87 in the first season and 39.18 and 43.62 in the second season were obtained from the untreated plants. However, the obtained values of plant height were 50.79- 58.80 and $55.55-64.28 \mathrm{~cm}$ (first season), 48.20- 56.28 and 49.82 $56.26 \mathrm{~cm}$ (second season) for the treatments of 10 and $20 \mathrm{ml} / \mathrm{L}$, respectively.

Thus, all concentrations of ALE under this study led to an increase in the plant height of sage. Such increment may be attributed to the effect of ALE on growing plant tissue. It is worth to mention that, ALE increases cell membrane permeability, oxygen uptake, respiration and photosynthesis, root and cell elongation and ion transport and effects on different factor of plant 
growth (Dongzhi et al., 2004; Padmaja et al., 2007; ElShayeb, 2009).

\section{Number of leaves / plant:}

It is clear from Tables $(2 \& 3)$ that all concentrations of ALE caused a significant increase in the number of leaves developed per plant than that obtained with control in the two seasons and its cuts.

In addition, a gradual increase in number of leaves / plant was induced as ALE concentration increased. The highest numbers of leaves/plant during the two seasons were 79.00 and 84.00 in the first season and 80.33 and 85.17 in the second season for the two cuts, respectively were obtained with the ALE at $40 \mathrm{ml} / \mathrm{L}$. On the other side, the lowest values of leaf number as 40.25-39.00 and 43.25 - 39.08 leaves/ plant were recorded with control plants in the two seasons and cuts, respectively.

The obtained results are in line with the findings of Mady (2008) \& Hamouda et al. (2012).

\section{Average of leaf area $\left(\mathrm{cm}^{2}\right)$ :}

As shown in Tables $(2 \& 3)$ in both seasons, ALE at all concentrations were not capable of inducing actual effects on leaf area of sage plants which significantly decreased than the control. The treatment with ALE at $40 \mathrm{ml} / \mathrm{L}$ significantly produced the least leaf area of leaves as $3.37-3.72$ and $3.15-3.34 \mathrm{~cm}^{2}$ in the first season and in the second season. The decrement in the leaf area was significant in all the treatments with ALE at 10 and $20 \mathrm{ml} / \mathrm{L}$, in comparison with control.

The effect of ALE on leaf area was not found in the concerned literature. It could be noticed that the reductive effect of ALE on leaf area was achieved relative to increasing the number of leaves and the number of main branches per plant.

\section{Number of main branches /plant:}

Data presented in Tables $(2 \& 3)$ show that the main branches /plant was increased by increasing ALE. Likewise, the higher concentration $(40 \mathrm{ml} / \mathrm{L})$ gave a significant increase in both seasons as compared to control, The main number of branches /plant during the two growing seasons were (10.19 - 8.83 and 9.66, 8.44), (11.94 - 11.86 and 11.77- 10.69) and (14- 13.75 and $13.75-13.83$ ) in response to $10,20 \& 40 \mathrm{ALE} / \mathrm{L}$ for the two cuts of the two seasons, respectively.

These findings may be due to the effect of ALE in enhancing plant growth. In this respect, Hanafy et al. (2012) stated that the direct effect of ALE on plant growth is to increasing substances penetration to plant membrane, effect the dry matter production and the uptake of nutrient by plant.

\section{Fresh weight of herb /plant (gm):}

Data presented in Tables ( $2 \& 3)$ show clearly that the number of main branches per plant was markedly affected by different ALE levels. The three treatments with ALE produced more fresh weight of herb, while the treatment which received no ALE carried less fresh weight of herb.

The highest weights were noticed in plants treated with ALE concentrations of $20 \mathrm{ml} / \mathrm{L}$ as $51.97 \& 48.53$ and $47.90 \& 51.29$ in the first season and second one the treatment with $40 \mathrm{ml} / \mathrm{L}$ gave the highest values as 60.37 $\& 57.50 \mathrm{~g}$ and $85.44 \& 62.03$ two cuts in the first and second seasons respectively.
The increment of such parameter could be attributed to the role of ALE in stimulating plant growth by the assimilation of major and minor elements, enzyme activation, changes in membrane permeability protein synthesis and activation of biomass production. (Sheikh et al., 2013).

The findings of Youssef (1997) and Nour El-Din (2005) who emphariged the effect of ALE on increasing branches of plants.

\section{Dry weight of herb/plant (gm):}

As shown in Tables $(2 \& 3)$ in both seasons, ALE at all levels caused a significant increase on the dry weight/plant over the control. The dry weight /plant were (48.95- 48.95 and $52.45-41.63 \mathrm{gm})$ with higher ALE level as compared to (10.56 -12.86 and 15.68$17.19 \mathrm{gm}$ ) with control in both seasons, respectively.

\section{Essential oil percentage in the herb:}

Result in Tables $(2 \& 3)$ revealed that the three levels of ALE gradually increased essential oil percentage in both seasons. These increments were statistically significant compared to untreated plants, except the lower concentration of ALE at $10 \mathrm{ml} / \mathrm{L}$ in the first cut of the first season only. The most effective treatments were the medium and higher concentrations (20\&40ml/L). Likewise, the highest values of the essential oil percentage were ranged between $1.85 \%$ $1.74 \%$ and $1.55 \%-1.66 \%$ compared to the control as $1.48 \%-0.93 \%$ and $0.95 \%-0.88 \%$ in the both seasons.

These results are agreed with Hamouda et al. (2012) and Ahmed et al. (2014) on sweet basil.

The stimulating effect of (ALE) on the previous vegetative characters may be explained on the concept of that aloe extract contains several physiological active constituents such as tryptophan which is the precursor of auxin, zinc also help in this way and endogenous gibberellins as well as other active compounds to stimulating cell division.

\section{Effect of ALE, on leaf anatomy structure of sage plants}

Microscopical counts and measurements of certain anatomical characters in transverse sections through the blade of sage leaf of control plants and of those sprayed with $40 \mathrm{ml}$ (ALE)/L are given in Table (4) likewise, microphotographs illustrating these treatments are shown in Fig. (1).

It is clear from Table (4) and Fig (1) that spraying ALE at concentration of $40 \mathrm{ml} / \mathrm{L}$ increased thickness of leaf blades, spongy tissue, mesophyll tissue and midvein of sage plant by $9.7,49.1,8.5$ and $0.7 \%$ more than the control, respectively. However, the thickness of palisade tissue was decreased by $1.4 \%$ lower than the control.

Likewise, the vascular bundle of the midvein was increased in size as a result of spraying ALE. The increment was mainly due to the moderately increase in width by $19.2 \%$ over the control and slightly lower in length by $6.9 \%$ than once.

It is clear also that, the decrease in length $(-6.9 \%)$ and increase width (19.2\%) of vascular bundle were accompanied with increment in width of both xylem $(12.7 \%)$ and phloem $(+17.3 \%)$ and decrement in length of both xylem $(-6.6 \%)$ and phloem $(-12.7 \%)$ tissue as compared to the control. 
Table (2): Effect of (ALE) on vegetative growth and oil percentage of two cuts of sage (Salvia officinalis L.) plants during first season

\begin{tabular}{|c|c|c|c|c|c|c|c|}
\hline $\begin{array}{l}\text { Aloe leaf } \\
\text { extract } \\
\text { treatments } \\
\text { (ml / liter) }\end{array}$ & $\begin{array}{l}\text { Plant } \\
\text { height } \\
\text { (cm) }\end{array}$ & $\begin{array}{c}\text { Number of } \\
\text { leaves } \\
\text { /plant }\end{array}$ & $\begin{array}{l}\text { Leaf area } \\
\quad\left(\mathrm{cm}^{2}\right)\end{array}$ & $\begin{array}{l}\text { Number of } \\
\text { main } \\
\text { branches } \\
\text { /plant }\end{array}$ & $\begin{array}{c}\text { Fresh } \\
\text { weight } \\
\text { of herb/ } \\
\text { plant (gm) }\end{array}$ & $\begin{array}{c}\text { Dry weight } \\
\text { of herb/ } \\
\text { plant (gm) }\end{array}$ & $\begin{array}{c}\text { Oil } \\
\text { percentage } \\
(\%) / 100 \\
(\text { gm) F.W. }\end{array}$ \\
\hline \multicolumn{8}{|c|}{ First cut of season (2012) } \\
\hline 0.0 & 42.93 & 40.25 & 8.98 & 6.63 & 19.12 & 10.56 & 1.48 \\
\hline 10 & 50.79 & 56.50 & 5.30 & 10.19 & 36.61 & 29.46 & 1.53 \\
\hline 20 & 55.55 & 64.67 & 4.45 & 11.94 & 51.97 & 41.70 & 1.64 \\
\hline 40 & 64.38 & 79.00 & 3.37 & 14.00 & 60.37 & 48.95 & 1.85 \\
\hline L.S.D 0.05 & 2.32 & 2.93 & 0.89 & 0.55 & 2.40 & 1.61 & 0.06 \\
\hline \multicolumn{8}{|c|}{ Second cut of season (2012) } \\
\hline 0.0 & 38.87 & 39.00 & 10.44 & 5.28 & 19.72 & 12.86 & 0.93 \\
\hline 10 & 58.80 & 62.50 & 6.80 & 8.83 & 38.07 & 30.80 & 1.28 \\
\hline 20 & 64.28 & 74.50 & 4.93 & 11.86 & 48.53 & 41.70 & 1.51 \\
\hline 40 & 70.75 & 84.00 & 3.72 & 13.75 & 57.59 & 48.95 & 1.74 \\
\hline L.S.D 0.05 & 1.79 & 3.07 & 0.39 & 0.62 & 2.31 & 2.28 & 0.19 \\
\hline
\end{tabular}

Table (3): Effect of (ALE) on vegetative growth and oil percentage of two cuts of sage (Salvia officinalis L.) plants during second season 2013

\begin{tabular}{|c|c|c|c|c|c|c|c|}
\hline $\begin{array}{l}\text { Aloe leaf } \\
\text { extract } \\
\text { treatments } \\
\text { (ml / liter) }\end{array}$ & $\begin{array}{c}\text { Plant } \\
\text { height } \\
(\mathrm{cm})\end{array}$ & $\begin{array}{l}\text { Number of } \\
\text { leaves } \\
\text { /plant }\end{array}$ & $\begin{array}{c}\text { Leaf area } \\
\left(\mathrm{cm}^{2}\right)\end{array}$ & $\begin{array}{c}\text { Number of } \\
\text { main } \\
\text { branches } \\
\text { /plant }\end{array}$ & $\begin{array}{c}\text { Fresh } \\
\text { weight } \\
\text { of herb/ } \\
\text { plant (gm) }\end{array}$ & $\begin{array}{l}\text { Dry weight } \\
\text { of herb/ } \\
\text { plant(gm) }\end{array}$ & $\begin{array}{c}\text { Oil } \\
\text { percentage } \\
(\%) / 100 \\
(\mathrm{gm}) \mathrm{F} . W . \\
\end{array}$ \\
\hline \multicolumn{8}{|c|}{ First cut of season (2013) } \\
\hline 0.0 & 39.18 & 43.25 & 8.96 & 5.30 & 18.87 & 15.68 & 0.95 \\
\hline 10 & 48.20 & 60.08 & 5.73 & 9.66 & 36.11 & 29.42 & 1.38 \\
\hline 20 & 56.28 & 68.33 & 4.65 & 11.77 & 47.90 & 41.93 & 1.41 \\
\hline 40 & 66.79 & 80.33 & 3.15 & 13.75 & 58.44 & 52.45 & 1.55 \\
\hline L.S.D 0.05 & 2.06 & 3.67 & 0.31 & 0.47 & 2.01 & 4.25 & 0.26 \\
\hline \multicolumn{8}{|c|}{ Second cut of season (2013) } \\
\hline 0.0 & 43.62 & 39.08 & 10.98 & 5.27 & 23.17 & 17.19 & 0.88 \\
\hline 10 & 49.82 & 58.67 & 5.81 & 8.44 & 37.19 & 29.36 & 1.32 \\
\hline 20 & 56.26 & 73.00 & 4.51 & 10.69 & 51.29 & 34.88 & 1.50 \\
\hline 40 & 67.24 & 85.17 & 3.34 & 13.83 & 62.03 & 41.63 & 1.66 \\
\hline L.S.D 0.05 & 2.16 & 2.51 & 0.23 & 0.56 & 2.36 & 2.45 & 0.14 \\
\hline
\end{tabular}


Table (4): Effect of foliar application with (ALE) at $40 \mathrm{ml} / \mathrm{L}$ on leaf anatomical structure of sage plant (means of three sections from three specimens)

\begin{tabular}{|c|c|c|c|}
\hline \multirow{2}{*}{ Anatomical structure } & \multicolumn{3}{|c|}{ Treatments } \\
\hline & Control & $40 \mathrm{ml}(\mathrm{ALE}) / \mathrm{L}$ & $\pm \%$ to control \\
\hline Thickness of blade $(\mu \mathrm{m})$ & 201.4 & 220.9 & +9.7 \\
\hline Thickness of palisade tissue $(\mu \mathrm{m})$ & 103.7 & 102.3 & -1.4 \\
\hline Thickness of spongy tissue $(\mu \mathrm{m})$ & 49.3 & 73.5 & +49.1 \\
\hline Thickness mesophyll tissue $(\mu \mathrm{m})$ & 162.8 & 176.7 & +8.5 \\
\hline Thickness of midvein $(\mu \mathrm{m})$ & 632.5 & 637.2 & +0.7 \\
\hline Length of vascular bundle $(\mu \mathrm{m})$ & 271.2 & 252.6 & -6.9 \\
\hline Width of vascular bundle $(\mu \mathrm{m})$ & 359.1 & 427.9 & +19.2 \\
\hline Length of xylem tissue $(\boldsymbol{\mu m})$ & 169.8 & 158.6 & -6.6 \\
\hline Width of xylem tissue ( $\mu \mathrm{m})$ & 337.7 & 380.5 & +12.7 \\
\hline Length of phloem tissue $(\mu \mathrm{m})$ & 99.1 & 86.5 & -12.7 \\
\hline Width of phloem tissue $(\mu \mathrm{m})$ & 368.8 & 432.5 & +17.3 \\
\hline No. of xylem arm/midvein bundle & 27.7 & 35.3 & +27.4 \\
\hline No. of xylem vessels/ arm & 10.7 & 12.3 & +22.4 \\
\hline
\end{tabular}

A



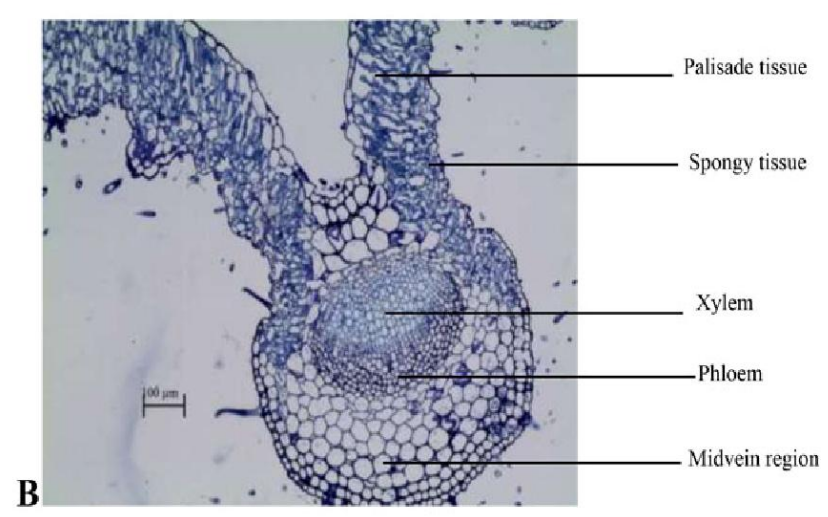

Fig. (1): Transverse sections through leaf blade of sage plant as affected by foliar application with aloe leaves extract (ALE) at40ml/L. A- From untreated plant (control), B- From plant sprayed with 40ml (ALE)/L.

In addition, number of both xylem arm/midvein bundle and xylem vessels/arm were increased by 27.4 and $22,4 \%$ more than the control, respectively.

The stimulating effect of foliar application with ALE on most included tissues of leaf sage plant attributed to organic compounds in such extract(nutrients, amino acids, hormones and vitamins) (Rajeswari et al, 2012; Sahu et al., 2013 and Sheikh et al., 2013) .

The beneficial effect of organic compounds towards leaf anatomical characters could be explained to the effect in protein synthesis and in turn promotes vascular differentiation and increasing cell division and expansion and this in turn reflected in an increase of vascular tissues.

Reports on the effect of spraying ALE on anatomical structure of vegetative organs of sage plant or other related species are not available in the literature. However, some studies has been done of the effect of plant natural extracts on anatomical structure of some kind of plants. It is worth mention that Abdo et al. (2012) and Nassar et al. (2015) found that garlic or yeast extracts application on soyabean or basil plants led to induce the increasing in thickness of leaf plade, palisade tissue, spongy tissue and vascular bundle of such leaves.

\section{REFERENCES}

Abdo, Fatma. A., Daila M. A. Nassar, Elham. F. Gomaa and Rania. M. A. Nassar (2012). Minimizing the harmful effects of cadmium on vegetative growth, leaf anatomy, yield and physiological characteristies of soyabean plant (Glycine max L.) by foliar spray with active yeast extract or 
with garlic cloves extract. Research Journal of Agriculture and Biological Sciences, 8(1): 24-35.

Ahmed, Shadia. K., K. H. A. Hammam and Alia A. Amer (2014). Effect of bio- fertilization and some plant extracts on the growth, yield and chemical constituents of basil plants. J. Plant Production, Mansoura Univ., 5 (2): 193-210.

British Pharmacopeia (1963). Determination of Volatile Oils in Drugs the Pharmaceutical Press, 17 Bloomsbury Square, London, and WCI.

Dongzhi, L., E. Tsuzuki, Y. Sugimoto, D. Yanjun, M. Matsuo and H. Terao (2004). Allelopathic effects of aqueous Aloe vera leaf extract on selected crops. Statistical Allelopathy J., 13: 67-74.

El-Shayeb, Nahed S. A. (2009). Physiological Studies on Oenothera biennis bio- fertilizer and plant extracts. Ph.D. Thesis, Hort. Dept. Fac. Agric. Benha Univ, Egypt.

Hamouda, A. M. A., Dina M. G. Hendi and Omneya F. A. Abu-El-Leel (2012). Improving basil growth, yield and oil production by Aloe vera extract and active dry yeast. Egypt J. Hort., 39(1): 45-71.

Hanafy, M. S., F. M. Saadaway and R. M. Ali (2012). Effect of some Natural extract on growth and chemical constituents of Schefflera arboricola plants. J. Hort. Sci. \& Ornamental plants, 4(1): 26-33.

Mady, A. (2008). Effect of certain medicinal plant extracts on growth, yield and metabolism of some medicinal and aromatic plants. (M.Sc. Thesis) Fac. Science Al-Azher Univ, Egypt.

Ministry of Agriculture (2016). Bulletin of The Agricultural Statistics, Total area for medical, aromatic and cutting flower plants in A.R.E., Economic Affairs Sector Ministry of Agriculture and Land Reclamation, Arab Republic of Egypt.

Nassar, M. A. and K. F. EL-Sahhar (1998): Botanical Preparations and Microscopy (Microtechnique). Academic Bookshop, Dokki, Giza, Egypt. 219 pp. (In Arabic).

Nassar, M. A., M. U. El-Segai and S. N. Azoz (2015). Influence of foliar spray with yeast extract on vegetative growth, yield of fresh herb, anatomical structure, composition of volatile oil and seed yield components of basil plant (Ocimum basilicum L.). International Journal of advanced Research, 3(10): 978-993.

Nour El-Din, T. (2005). Physiological studies on marjoram plants (Majorana hortensis M.). M.Sc. Thesis of Ornamental Horticulture Department Faculty of Agriculture at Moshtohor Zagazig University (Banha Branch).

Padmaja, C. K., B. Kowsalya and C. Seethalakshmi (2007). Efficacy of Aloe vera leaf powder as biostimulant in enhancing the growth and yield of Lady's Finger (Abelmoschus esculentus L.) Research on Crops, 8: 395-397.

Raman Rao, P. V., S. Rita Raghuvanshi, B. C. Mondal and S. K. Singh (2013): Effect of Aloe vera and clove powder supplementation on carcass characteristics, composition and serum enzymes of Japanese quails. Vet. World, 8(5): 664-668.

Rajeswari, R., M. Umadevi, S. C. Rahale, R. Pushpa, K. P. Selvavenkadesh, S. Kumar and D. Bhowmik (2012). Aloe vera: The Miracle Plant Its Medicinal and Traditional Uses in India. J. of Pharmacognosy and Phytochemistry, '(4): 118124.

Sahu, K. P., D. D. Giri, R. Singh, P. Pandey, S. Gupta, A. K. Shrivastava, A. Kumar and D. K. Pandey (2013). Effect of Aloe vera on some annual plants Sci. Res. Pharmacology and Pharmacy, 4, 599-610.

Sheikh, F. A., R. P. P. Singh and P. Lehana (2013). Effect of high voltage on the resistance of Aloe vera Leaves. (IJRTE), 2(3): 42-45.

Shyamal, K. N., M. P. Lok and W. P. Charles (1990). Dynamics of endogenous cytokinins during the growth cycle of a hormone- autorophic genetic tumor line of Tobacco. Plant Physiology, 94: 1084-1089.

Snedecor, G. W and W. G. Cochran (1980). Statistical Methods $7^{\text {th }}$ Edition. Iowa state Univ. press. Amer. Iowa, U.S.A.

Youssef, H. M. A. (1997). Physiological studies on some annual plants. M. Sc. Thesis, Fac. of Agric., Moshtohor, Zagazig Univ, Egypt.

\section{تأثير الرش بمستخلص أوراق الصبار على النمو الخضري والمحصول والزيت والتركيب التشريحي لورقة نبات المريميه تحت ظروف الأرو اضئي الرملية

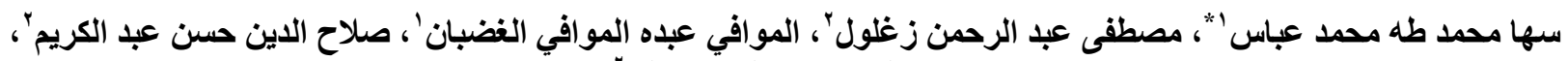

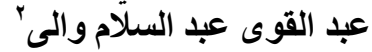 \\ ' قسم بحوث النباتات الطبية و العطرية ـ معهد بحوث البساتين ـ مركز البحاثل البحوث الزر اعية ـ الجيزة ـ مصر

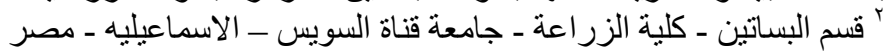





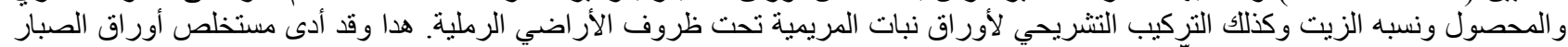

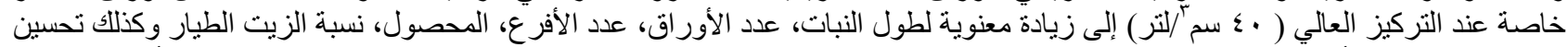



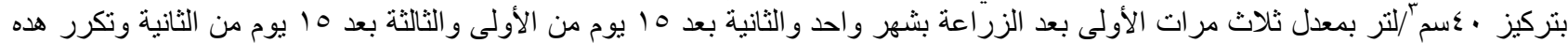
العملية بعد القرطه الأولى. 